\title{
Role and Utility of Accreditation in Management Education ${ }^{1}$
}

\author{
N. P. Singh \\ Professor (IT) \\ Management Development Institute \\ Mehrauli Road, Sukhrali, \\ Gurgaon -122007, India \\ e-mail: knpsingh@mdi.ac.in \& netra.singh@gmail.com
}

\begin{abstract}
The research paper presents the role and utility of quality assurance and accreditation in management education in the context of India. It includes the analysis of present quality assurance and accreditation mechanism of management education in India in terms of (i) accreditation organizations viz-a-vis number of management educational institutions, (ii) the evaluation parameters of different accreditation agencies, (iii) entry and acceptability of international accreditation agencies, and (iv) impact of accreditation on management education. In addition, paper suggests role of social media and it's connect with quality assurance and accreditation of education in general and management education in specific terms.
\end{abstract}

Keywords: Accreditation, EQUIS, NBA, AIU, AMBA, SAQS, AACSB

\section{Introduction}

Post Graduate Management education in India offer programs tailored to full-time, part-time, executive, and distance-learning students, with specialized subject concentrations such as marketing, finance, information technology, human resources etc., The delivery models of management education in India includes (i) two years university model which is called either semester system or trimester system \& awards MBA degrees (ii) two years Indian Institute Management model which is very similar to trimester system of the universities but award PGDM (Post Graduate Diploma in Management), and (iii) less than two years full time management education model for working executives which also award PGDM. For the part time PGDM which is also for working executives, the requirement of the duration is three years. However, there are some variations within each model mainly in terms of outside class room activities. The entry of international educational institutions will also result in new formal \& informal delivery model with different format. This growth of management institutions in India resulted in to liberal policies of admission and examination. In turn, it has resulted in to poor quality of graduating students in some cases, shortage of academic staff, and creation of non-competitive environment. The liberal policies of management education and market job scenario had even forced students in the recent past to opt for traditional masters programs of the government supported universities and their affiliated colleges in comparison to two years management programs offered by new MBA colleges. The

\footnotetext{
${ }^{1}$ Presented at $2^{\text {nd }}$ World Summit on Accreditation (WOSA-2014), $8^{\text {th }}-10^{\text {th }}$ March, 2014 at Hotel Ashok, New Delhi, India.
} 
entry of national \& international institutions in the role of universities coupled with the liberal policies and role of social media which in some cases may be used as an instrument to lure students; will require external stringent validation and accreditation of institutions to maintain strong quality assurance which can safeguard the rights of stakeholders.

In the environment of high growth of number of management institutions in India, accreditation become very important since it helps in improving the quality of teaching, research, and management / administration of the academic institutions of higher education. It is expected that accreditation process will bring accountability in higher education and facilitate the institutions to achieve their objectives such as adoption of best teaching and evaluation practices. In turn it will help these institutions to produce better quality professionals. Accreditation processes are also accountable in enhancing the knowledge of academic community since it requires innovations \& research from faculty / institutions. Further, institutions when plan to go under accreditation processes do their best to improve their activities including teaching, research, training, and networking with stake holders of eco-system such as other academic institutions, alumni, industry, and government agencies. Accreditation process is an additional public scrutiny of academic institutions \& will force governing boards to devote more time to look in depth accreditation processes to meet new demands \& expectations [1]. Accreditation process also helps in improving quality of the education $[4,9]$.

In the present scenario where business education is losing its shine accreditation of the business schools makes more sense to improve quality of business education. Keeping this in view, present research note presents some suggestions to the accreditation processes in the context of management education. The major source of information is the author's involvement in accreditation processes of National Board Accreditation (NBA), Association of MBAs (AMBA), South Asian Quality Assurance System (SAQS), Association of Indian universities (AIU), research papers published on the topic and other data from secondary source on the subject specifically from Internet.

\section{Accreditation Management Educational Institutions:}

Associated Chambers of Commerce and Industry of India (ASSOCHAM) reported that MBA seats in India grew almost four-fold from 95,000 in 2006-07 to 360,000 in 2011-12 [5]. According to another source it has crossed the Figure of 385000 (http://en.wikipedia.org). It means, it has resulted in a five-year compounded annual growth rate of 30 per cent. This is a complete mismatch with growth rate of Indian economy during the same period. It is, therefore, resulted in to closer of many management institutes in the last few years but still the number is very large. Accreditation of such a large population of management institute is a very difficult task for one organization, i.e., National Board of Accreditation (NBA) in this case which also responsible of accreditation of technical institutions in India. Secondly, all management institutes are not of the same level in term of quality of their students and delivery systems. Accreditation with one standard may not bring many of them in to the family of accreditation certificate holders. Many times when teams evaluate the institution, they are not able to differentiate between minimal infrastructure, optimal infrastructure, and state of the art infrastructure. It may discourage some of the institutions to even file applications for accreditation. To encourage, the management institutions, there is a need to think of multi layer accreditations rather than one layer accreditation system. It may necessitate creation of a separate institution for accreditation of management education in India or to have more resources with NB A. 
This is needed more if accreditation is must for all management education institutions as pointed out by policy makers in the country.

\section{Evaluation Parameters of Different Accreditation Agencies}

The accreditation organization includes almost similar parameters with some variations either in the weightage or in sub-parameters for the purpose of evaluation of academic as well technical institutions. To mention NBA evaluation in India includes the following parameters as given in Table 1. These parameters are often referred as input-process-output matrix.

Table 1. Parameters of NBA for Accreditation of Management Schools in India

\begin{tabular}{|c|c|c|}
\hline Input (Enablers) & Process & Output \\
\hline $\begin{array}{l}\text { Student/Admission } \\
\text { process }\end{array}$ & $\begin{array}{l}\text { Teaching \& Learning } \\
\text { Processes }\end{array}$ & Academic Results \\
\hline $\begin{array}{ll}\text { Faculty/ faculty } \\
\text { Recruitment }\end{array}$ & Placement process & Placement \\
\hline $\begin{array}{l}\text { Standards that relates } \\
\text { to the learning goals }\end{array}$ & $\begin{array}{l}\text { Research \& Development } \\
\text { Process }\end{array}$ & $\begin{array}{l}\text { Value and Ethic } \\
\text { centric Outcomes }\end{array}$ \\
\hline Physical Infrastructure & Leadership \& Governance & $\begin{array}{l}\text { Entrepreneurship and } \\
\text { Job Creation }\end{array}$ \\
\hline IT Infrastructure & $\begin{array}{l}\text { MDP and Consultancy } \\
\text { Processes }\end{array}$ & Industry Interaction \\
\hline Library & $\begin{array}{lr}\text { Faculty } & \text { Appraisal, } \\
\text { Development } & \text { and } \\
\text { Promotion Processes } & \end{array}$ & MDPs \\
\hline Global Input & $\begin{array}{l}\text { Internationalization } \\
\text { Processes }\end{array}$ & $\begin{array}{l}\text { International/ Global } \\
\text { Reach \& Linkages }\end{array}$ \\
\hline $\begin{array}{l}\text { Quality } \\
\text { Policy }\end{array}$ & $\begin{array}{lr}\text { Staff } & \text { Appraisal, } \\
\text { Development } & \text { and } \\
\text { Promotion Processes } & \\
\end{array}$ & Research \& Innovation \\
\hline Finances & $\begin{array}{ll}\text { Student } & \text { Overall } \\
\text { Development } & \\
\end{array}$ & $\begin{array}{l}\text { Stakeholder's } \\
\text { Satisfaction }\end{array}$ \\
\hline & $\begin{array}{l}\text { Curriculum Development } \\
\text { Processes }\end{array}$ & $\begin{array}{l}\text { Contribution to the } \\
\text { Society }\end{array}$ \\
\hline
\end{tabular}

On the other hand AACSB philosophy is around five stakeholders. These five stakeholders are (i) students, (ii) parents, (iii) counselors, (iv) faculty, and (v) recruiters. AACSB accreditation process extends value for money/resources to all the five stakeholders. It is based on four parameters consisting of 15 standards as listed in Table 2.

Table 2. AACSB Accreditation Standards/ Parameters

\begin{tabular}{|l|l|l|}
\hline Parameters & Standard & Sub-Parameters \\
\hline $\begin{array}{l}\text { Strategic Management } \\
\text { and Innovation Standards }\end{array}$ & Standard 1 & Mission, Impact, And Innovation \\
\hline & Standard 2 & $\begin{array}{l}\text { Intellectual Contributions, Impact, } \\
\text { and Alignment With Mission }\end{array}$ \\
\hline & Standard 3 & Financial Strategies and \\
\hline
\end{tabular}




\begin{tabular}{|l|l|l|}
\hline & & Allocation of Resources \\
\hline $\begin{array}{l}\text { Participants-Students, } \\
\text { Staff }\end{array}$ & Standard 4 & $\begin{array}{l}\text { Student Admissions, Progression, } \\
\text { and Career Development }\end{array}$ \\
\hline & Standard 5 & $\begin{array}{l}\text { Faculty Sufficiency and } \\
\text { Deployment }\end{array}$ \\
\hline & Standard 6 & Faculty Management And Support \\
\hline $\begin{array}{l}\text { Learning and Teaching } \\
\text { Standards }\end{array}$ & Standard 7 & $\begin{array}{l}\text { Professional Staff Sufficiency } \\
\text { And Deployment }\end{array}$ \\
\hline & Standard 8 & $\begin{array}{l}\text { Curricula Management And } \\
\text { Assurance Of Learning }\end{array}$ \\
\hline & Standard 9 & Curriculum Content \\
\hline & Standard 10 & Student-Faculty Interactions \\
\hline & Standard 11 & $\begin{array}{l}\text { Degree Program Educational } \\
\text { Level, Structure, and Equivalence }\end{array}$ \\
\hline $\begin{array}{l}\text { Academic and } \\
\text { Professional Engagement }\end{array}$ & Standard 12 & Teaching Effectiveness \\
\hline \multicolumn{2}{|l|}{ Standard 13 } & $\begin{array}{l}\text { Student Academic } \\
\text { Professional Engagement }\end{array}$ \\
\hline & Standard 14 & Executive Education \\
\hline Source: http://accredited.aacsb.edu/ & $\begin{array}{l}\text { Faculty Qualifications and } \\
\text { Engagement }\end{array}$ \\
\hline
\end{tabular}

There are variations in the accreditation processes. Some accreditation organizations do the accreditation of management institutions as a whole, while others do it for particular programs of the management institute. Every record submitted by the institutions is physically verified by visiting teams of accreditation organizations. There are some changes which need to be looked in to by accreditation organizations. These are:

There is a need to reduce the some of the parameters for the purpose of physical inspection. To mention, research output can be verified from records of the institutions such as audited annual reports which are more authenticated or can be taken from many social media websites. Another important issue for consideration is that there are large number of business schools (tier- 2 \& tier 3 categories) with no international relations or collaborations but they can play a big role in creating entrepreneurs in a market which lacks jobs for many. In fact many of them are playing these roles. The weightage of international dimension should be reduced to zero in such cases. In addition, there are many other parameters of the evaluation where new business schools in remote locations of the country do not stand a chance to score. Therefore, there is a need to take in to account existing management education scenario (geographical locations etc.,) of the country while designing accreditation processes. As a suggestion accreditation can be done at state level and national level. It will certainly prompt management institutions to file their applications for accreditation and harvest the benefits of the exercise.

\section{Entry and Acceptability of International Accreditation Agencies}

The top business schools are very keen to have international accreditation. The acceptability of international accreditation agencies is very high among top B-schools in India [3]. The major agencies are (i) The European Quality Improvement System (EQUIS), (iii) The Association to Advance Collegiate Schools of Business (AACSB), (iii) Association of 
MBAs (AMBA), and (iv) South Asian Quality Assurance System (SAQS). In addition to these four few other agencies such as Association of Collegiate Business Schools and Programs (ACBSP), International Accreditation Organization (IAO) USA, are also visiting Indian B-schools and had extended accreditation to few business schools in India (http://psgim.ac.in/discover-psgim/accreditations/ \& http://www.ims-ghaziabad.ac.in/).

However, India is far behind China and Korea in international accreditation [2]. Further to it, there are certain issues with international accreditation agencies. These issues are (i) cost, (ii) time, (iii) rigor, and (iv) location disadvantages for Indian institutions with respect to internationalization parameter. In addition, Indian Management Journals are not yet part of impact factor which is another reason for low scores of Indian management schools on research dimension. Further, the curriculum of European institutions is different from Indian management institutions. Even there is a wide gap between management faculties of European and Indian Business schools as shown in Table 3.

Table 3. Comparison of Areas of Management in Europe \& India

\begin{tabular}{|c|c|c|c|}
\hline $\begin{array}{l}\text { ESCP Paris, } \\
\text { France }\end{array}$ & HHL Leipzig & IIM Ahemdabad & MDI Gurgaon \\
\hline $\begin{array}{c}\text { Economics, Law } \\
\text { and Social } \\
\text { Sciences }\end{array}$ & $\begin{array}{l}\text { Accounting \& } \\
\text { Auditing }\end{array}$ & Business Policy & $\begin{array}{c}\text { Business } \\
\text { Communications }\end{array}$ \\
\hline Finance & $\begin{array}{l}\text { International } \\
\text { Management }\end{array}$ & $\begin{array}{c}\text { Center for } \\
\text { Management in } \\
\text { Agriculture }\end{array}$ & Economics \\
\hline $\begin{array}{c}\text { Financial } \\
\text { Reporting \& Audit }\end{array}$ & IT based Logistics & Communications & Finance \\
\hline $\begin{array}{l}\text { Information \& } \\
\text { Operations } \\
\text { Management }\end{array}$ & $\begin{array}{l}\text { M\&A of Small \& } \\
\text { Midsized Entities }\end{array}$ & Economics & $\begin{array}{c}\text { Human Behavior \& } \\
\text { Organizational } \\
\text { Development }\end{array}$ \\
\hline $\begin{array}{l}\text { Language \& } \\
\text { Culture }\end{array}$ & Macroeconomics & $\begin{array}{l}\text { Finance \& } \\
\text { Accounting }\end{array}$ & $\begin{array}{l}\text { Human Resource } \\
\text { Management }\end{array}$ \\
\hline $\begin{array}{l}\text { Management } \\
\text { Control }\end{array}$ & Marketing & $\begin{array}{l}\text { Information } \\
\text { Systems }\end{array}$ & $\begin{array}{l}\text { Information } \\
\text { Management }\end{array}$ \\
\hline Marketing & Microeconomics & $\begin{array}{l}\text { Library \& } \\
\text { Information } \\
\text { Sciences }\end{array}$ & Marketing \\
\hline \multirow[t]{5}{*}{$\begin{array}{c}\text { Strategy, } \\
\text { Organizational \& } \\
\text { Human Resources } \\
\end{array}$} & $\begin{array}{c}\text { Strategic } \\
\text { Management \& } \\
\text { Family Business }\end{array}$ & Marketing & $\begin{array}{c}\text { Operations } \\
\text { Management }\end{array}$ \\
\hline & $\begin{array}{c}\text { Innovation } \\
\text { Management \& } \\
\text { Entrepreneurship }\end{array}$ & $\begin{array}{l}\text { Organizational } \\
\text { Behavior }\end{array}$ & $\begin{array}{c}\text { Public Policy \& } \\
\text { Corporate Law }\end{array}$ \\
\hline & $\begin{array}{c}\text { Financial } \\
\text { Management }\end{array}$ & $\begin{array}{c}\text { Personnel \& } \\
\text { Industrial Relations }\end{array}$ & $\begin{array}{c}\text { Strategic } \\
\text { Management }\end{array}$ \\
\hline & $\begin{array}{c}\text { Entrepreneurship \& } \\
\text { Technology } \\
\text { Transfer }\end{array}$ & $\begin{array}{c}\text { Production \& } \\
\text { Quantitative } \\
\text { methods }\end{array}$ & \\
\hline & $\begin{array}{l}\text { Economics \& } \\
\text { Information }\end{array}$ & $\begin{array}{l}\text { Public Systems } \\
\text { Group }\end{array}$ & \\
\hline
\end{tabular}




\begin{tabular}{|l|c|c|c|}
\hline & Systems & \\
\hline & $\begin{array}{l}\text { Economics \& } \\
\text { Business Ethics }\end{array}$ & $\begin{array}{c}\text { Educational } \\
\text { Innovation }\end{array}$ & \\
\hline & $\begin{array}{c}\text { Corporate } \\
\text { Responsibility \& } \\
\text { Governance }\end{array}$ & & \\
\hline Source: Websites of the institutions under reference & \\
\hline
\end{tabular}

Indian management school's faculty is still working under the old departmental system rather than creating special faculties in new areas such as innovation, Research \& Development Management, Entrepreneurship, technology transfer etc. This is a disadvantage to Indian Management Institutions.

\section{Impact of Accreditation on Management Education}

Not too many studies are reported recently with respect to the impact of accreditation process which is based on empirical evidences. Shah [6], Shukla [8], Shahaida [7] and other sources on Internet mentioned a big list of impacts of accreditation processes on management education in India. These accreditation impacts on management education are visible in many ways. Management institutions have created their brands with the help of these accreditations. Some of these impacts are summarized in the following:

a. It creates an environment of improving knowledge base of those who are imparting management education and for those who are involve in research activities.

b. It forces the organization to improve support services for teaching and research to meet the benchmarks of accreditation processes.

c. It is a new philosophy to share achievements, awarding the achievements in nonmonetary form.

d. It is eliminating many out dated processes of imparting knowledge and processes of managing the affairs of institutions who imparting education.

e. It acts as a catalyst in improving relations among all stakeholders of the education systems.

f. It is a feedback by the achievers of their achievements.

g. It emphasis on the need for change which is required to sustain quality of the existing system

h. It creates global mind sets.

i. It helps in networking with industry at national and international level because to get accreditations, institutions need to have international networking.

\section{Role of Social Media in Accreditation Process}

Rating and other academic data of the institutions available at various websites of social media such as researchgate.com, academia.edu, Google scholar, etc., should be included as one of the parameters by the accrediting organizations. It is highly unbiased rating by an independent organization. It may be part of international networking/outreach as a subparameter. It will prompt faculty members and research scholars to register and upload their research work on social networks. In turn, researchers as well as institute will achieve the following

a. It will help researchers / faculty to assess their work vis-à-vis work done by peers within and outside their organization.

b. It will provide quick access to the work of fellow researchers, 
c. It provides a continues feedback to institutions as well as individual researchers along with more data such as impact factor, access and citation of your work.

Recent research gate score (RG Scores) are given in Table 4 for the management institute in India and other institutions of India and world in Table 5. It is evident from the data given in two Tables that management schools though teach and do lots of research on social media but do not use it for the purpose of advertisement. The gap between world research institutions and Indian research institution RG score is vey huge. Similarly if one look at the gap between management institutions RG scores vis-a-viz other research institutions within India it is much higher. It is exactly in line with the brand image in the domestics as well as international market. It could be very useful parameters and will not require cost of measuring it.

Table 4. Research Gate Scores of Indian Management School

\begin{tabular}{|l|l|l|l|}
\hline SN & Institute & $\begin{array}{l}\text { Members of } \\
\text { Research } \\
\text { Gate }\end{array}$ & $\begin{array}{l}\text { Research } \\
\text { Gate Score }\end{array}$ \\
\hline $\mathrm{A}$ & Management Institutes & $\mathbf{2 8 . 0 2 . 1 4}$ & $\mathbf{0 6 . 0 3 . 1 4}$ \\
\hline 1 & IIM Ahemedabad & 213 & 218.94 \\
\hline 2 & IIM Bangalore & 139 & 209.96 \\
\hline 3 & IIM Kolkata & 69 & 123.52 \\
\hline 4 & IIM Lucknow & 62 & 107.52 \\
\hline 5 & MDI & 75 & 90.34 \\
\hline 6 & IIM Kozhikode & 66 & 60.23 \\
\hline 7 & IIM Indore & 72 & 49.59 \\
\hline 8 & IIM Udaipur & 8 & 21.35 \\
\hline 9 & IIM Raipur & 11 & 18.77 \\
\hline 10 & IIM Rohtak & 14 & 13.04 \\
\hline 11 & IIM Ranhi & 15 & 1.97 \\
\hline 12 & IIM Kashipur & 7 & 1.36 \\
\hline 13 & IIM Shillong & 6 & 1.10 \\
\hline
\end{tabular}

Table 5. Research Gate Score of Top Five Institute in World and India

\begin{tabular}{|l|l|l|l|}
\hline B & Top Indian Institute & $\mathbf{2 8 . 0 2 . 1 4}$ & $\mathbf{0 6 . 0 3 . 1 4}$ \\
\hline 01 & IISC Bangalore & 1987 & 9170.90 \\
\hline 02 & Bhabha Atomic Research Center & 887 & 7898.38 \\
\hline 03 & All India Institute of Medical Sciences & 853 & 7603.96 \\
\hline 04 & Indian Council of Medical Research & 699 & 6454.29 \\
\hline 05 & IIT Kharagpur & 1826 & 5785.44 \\
\hline C & Top World Institutes & & \\
\hline 01 & Chinese Academy of Sciences & 10444 & $94,301.84$ \\
\hline 02 & University of São Paulo, Brazil & 11529 & $84,639.26$ \\
\hline 03 & National Research Council, Italy & 4311 & $75,127.65$ \\
\hline 04 & $\begin{array}{l}\text { French National Centre for Scientific } \\
\text { Research, Paris }\end{array}$ & 3912 & $74,316.67$ \\
\hline 05 & Russian Academy of Sciences, Russia & 6015 & $73,122.32$ \\
\hline
\end{tabular}




\section{Conclusion}

Based on five points discussed in this research note following is concluded

a. There is a need to have differential accreditation process for different category of business schools in India. One could at state level and another at national level.

b. Large number of exhaustive set of parameters are included by the accreditation agencies but not fine tuned to the domestic needs. There is a need to include more local parameters.

c. Acceptability of international accreditation agencies is very high among top management schools in India but it is costly, cumbersome and time consuming processes. It is making an impact but still words like CAT (Common Admission Test) are more popular among masses in comparison to international accreditations.

d. The impact of accreditation is quite visible in business schools. It is visible more in case of top B-schools and it is helping them in creating brand.

e. There are millions users of social media across the world irrespective of their affiliations. They share their research works, thoughts, on these social media, therefore, social media rating of the management institutions must be given due space in the accreditation process specifically citation by Google scholar, scores of researchgate.com, data of academia.com etc.

\section{References}

[1] J. S. Eaton, "The Changing Role of Accreditation: Should It Matter to Governing Boards?, Trusteeship magazine", December. Retrieved on January 12, 2014 from http://www.chea.org/pdf/EatonChanging_Role_Accreditation.pdf, (2013).

[2] "MBS Universe", India lags China, Korea on global MBA Accreditation: AACSB COO tells, February, 24. Retrieved on March 3, 2014, from http://www.mbauniverse.com/article/id/7529/AACSB-COO, (2014).

[3] P. K. Nanda, "Indian B-schools opt for global accreditation", December 05. Retrieved on January 14, 2014 from http://www.livemint.com/Politics/70S5uvFDfLC7UUDBYqaw9J/Indian-Bschools-opt-for-globalaccreditation.html, (2014).

[4] R. Natarajan, "The Role of Accreditation in Promoting Quality Assurance of Technical Education", International Journal of Engineering Education, vol. 16, no. 2, (2000), pp. 85-96.

[5] "Press Releases, B-schools increasingly loosing shine in India", says ASSOCHAM, January 30. Retrieved on 15 February, 2014 from http://www.assocham.org/prels/shownews-archive.php?id=3877, (2011).

[6] G. G. Saha, "Management Education in India: Issues \& Concerns", Journal of Information, Knowledge and Research in Business Management and Administration, vol. 2, no. 1, (2012), pp. 35-40.

[7] P. Shahaida, H. Rajshekar and R. Nargundkar, "Quality of Management Education in India: Development of a conceptual framework", IMPACT, the IIM Indore Journal, vol. 2, no. 1, (2007), pp. 45-55.

[8] S. S. Shukla, "Management Education in India-Issues and Concerns", International Journal of Education and Learning, vol. 2, no. 2, (2013), pp. 15-26.

[9] N. Varma, "Accreditation: A Solution to Delivering Quality Education in the 21st Century", Retrieved on January 12, 2014 from http://www.indiaeducationreview.com/article/accreditation-solution-deliveringquality-education-21st-century, (2013).

\section{Author}

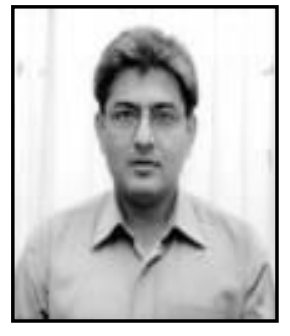

N. P. Singh, he holds M.S., M. Sc. and Ph. D degrees. He is presently working as Professor \& Dean (Research) at Management Development Institute, Gurgaon, India. Prior to joining MDI; he was Professor (Comp \& MIS) at National Institute of Financial Management Faridabad. He has also taught at Institute of Rural Management, Anand and CSS Haryana Agriculture University, Hisar, KIMEP, Almaty, Kazakhstan, Moscow State University, Moscow. His teaching, research, and training interests are 
Information Systems, Business Intelligence, Data Warehouse \& Data Mining; internet enabled technology, Telecommunication Business, Mathematical Modeling. He has published 80 articles in national and international journals. He has supervised research work of five Ph.D. Students. He is recipient of Young Scientist award. He has consulted with several government and semi government organization such as Asian Development Bank, UNICEF, FCI, NALCO, Department of Information Technology, Ministry of Information \& Communication \& Technology, Govt. of India, SPMCIL, Department of Consumer Affairs, NDDB, KMF, NEH Council, and Small Farmers Consortium, in the areas of Business Intelligence, Information systems, Software development, IT Application, Project Management, and Impact Analysis etc. 
International Journal of Education and Learning Vol.3, No.2 (2014) 